\title{
Development of Youth Entrepreneurship in the Russian Region
}

\author{
V.V. Smirnov, A.N. Zakharova*, A.G. Abramova, G.S. Dulina, V.L. Semenov \\ Chuvash State University, Cheboksary, Russia \\ *Corresponding author.Email:zaharova_an@mail.ru
}

\begin{abstract}
The subject of the study is the development of youth entrepreneurship in the Russian region. The aim of the work is to determine the role of young people as labour resources in the system of public production. The study is based on a systematic approach using methods of descriptive statistics. The study has revealed the increasing role of youth entrepreneurship in the new reality of the world economic system, its exceptional position in the structure of unemployment and poverty among working people. The article shows that all countries are active in solving problems caused by structural changes in the world economic system. In lowand middle-income countries measures for stimulation of self-employment and entrepreneurship prevail, while in high-income countries measures for employment services and job search assistance predominate. The specific nature of the Russian economy causes a shift of the goal-oriented vector of development towards entrepreneurship, concentrating responsibility for the standard of living on the individual. The opportunities of the economy of the Russian region Chuvashia together with the legal acts regulating entrepreneurial activity and the strategy of socio-economic development, concentrate the development of youth entrepreneurship in the industrial export sectors, in a special form developing mediation within the import substitution policy. The results of the study reveal a variety of approaches to solving the problem of youth entrepreneurship development, using the opportunities of the region's economy, forming new competencies pertaining to the state policy of reducing unemployment rate. Significant differences in the economies of Russian regions are an incentive for the development of youth entrepreneurship. A special determinant, being a part of the region's foreign economic activity and set as a priority in the Federal law on strategic planning, acts as a reduced functional basis of the Chuvash economy.
\end{abstract}

Keywords: opportunities of the region's economy, youth entrepreneurship, public production, selfemployment, employment services assistance, unemployment structure

\section{INTRODUCTION}

The problem of development of regional youth entrepreneurship in Russia is related not only to the gender aspects of labour resources employed in the system of production, distribution, exchange and consumption of goods, but also to the possibilities of the economy of a certain constituent entity of the Russian Federation. The inequality of opportunities for the development of youth entrepreneurship relative to the potential of the region is a source of self-motion of the Russian economy as a whole. Eighty-five constituent entities with stable contradictions in the development of youth entrepreneurship and the region's economy are a significant stimulating factor in the development of the Russian economy.

The study of the development of regional youth entrepreneurship as a phenomenon is associated with revealing contradictions. These contradictions, being a source of youth entrepreneurship self-motion, have become a condition for the development of the economy of a particular region and the Russian economy as a whole.
It's rather difficult to determine the region's economy position in the structure of the Russian economy in view of the insufficiently complete, constantly changing statistical data of the Federal state statistics service of the Russian Federation [1]. This difficulty creates contradictions that, on the one hand, make it impossible to express the results of the study not only as a detailed beginning, but as a whole. On the other hand, lack of clear and stable ideas about the development indicators of the regional and national economy allows us to reduce their self-motion to the functional basis, without experiencing discomfort in the absence of an accurate numerical result.

Reducing the regional economic development trends to the functional basis decreases an acute dependence on the conceptual apparatus and most of the requirements for the structural integrity of the study. This simplifies the research process, but it is still possible to reveal trends in economic development. Proceeding from the results of the reduced functional analysis and comparison of the development indicators of other regions, we can develop a holistic picture of the region's economy development.

As a reduced functional basis, we will distinguish import and export according to the Foreign Economic Activity Commodity Nomenclature (FEACN) [2] of the region, 


\section{METHOD}

planning in the Russian Federation" [3].

\section{THEORY}

Theoretical provisions for the development of youth entrepreneurship are quite simple to understand. They are described within the established laws of economic theory, in the section where the problem of development of society and industrial relations is studied by Marx, Engels, Lenin $[4,5]$. The change in the world order caused by a decline in world trade and increased global competition exacerbates contradictions in the development of society, which is based on the production of material goods $[6,7]$.

Young people with their ability to work come to the forefront of the problem of social development. At the same time, young people exist in a certain reality that has developed in the national economies of the world, namely:

- young people are the centrepiece in the structure of poverty rate among working people $[8,9]$;

- a decrease in GDP in low- and middle-income countries (LMICs) leads to a significant increase in youth unemployment $[10,11,12]$;

- in LMICs measures for stimulation of selfemployment and entrepreneurship prevail [13];

self-employment and entrepreneurship are concentrated in LMICs focusing on construction, agriculture, and street trade [14, 15]. Most self-employed jobs in LMICs are associated with low productivity and income, and as a result, many of the self-employed and their families remain poor.

It should be noted that in high-income countries (HICs) predominate measures for employment services and job search assistance (ESJSA) in the context of the main active labour market programmes/policy (ALMP) [16] including:

1) subsidized employment:

- public employment projects (programmes) (PEPs), such as infrastructure construction, community service, etc.;

- assistance in job creation in private business through wage subsidies for young people;

2) training young people in professional skills at work or outside work.

Thus, the current technological structure in the Russian economy, as a country of LMICs, does not imply the implementation of ESJSA activities, but to a greater extent stimulates self-employment and entrepreneurship, and specifically among young people. This leads to a considerable transformation of the economy towards "knowledge", as a necessary condition for the emergence of reactions of society members to work. The development of the Russian economy induces a "spin-off" from the large system of material goods production, entrepreneurship and self-employment. The natural vanguard of this process is youth, as part of labour resources, having no necessary knowledge and skills, but driven by economic and psychological motives to accruement, significantly joining the ranks of entrepreneurs and self-employed.
To assess the opportunities of the region's economy for the development of youth entrepreneurship, we apply methods of descriptive statistics, including the processing of empirical data, their systematization, visual representation, quantitative description through basic statistical indicators. The use of the descriptive statistics method will sufficiently reveal the laws of development of youth entrepreneurship in Chuvashia, including regularity and uniformity of entrepreneurial activity. In general, this is sufficient to identify stable trends in the development of youth entrepreneurship. With the help of descriptive statistics, in the diversity of reality we will distinguish the order of things, some stability within the observed diversity.

\section{ANALYSIS}

To understand and evaluate the opportunities for the development of youth entrepreneurship in Chuvashia, we should determine the characteristics of its economy. To do this, it is necessary to analyze the dynamics of ratios, the difference between ratios, as well as the ratio of differences between the main indicators of the economy of Chuvashia and the Russian Federation. The analysis of this dynamics has shown the following. First, high median values of the "Ratio of physical volume indices of GRP per capita (Chuvash Republic / Total for constituent entities of the Russian Federation), \%" $\left(\mathrm{Me}=99.21 \% ; 6^{2}\right.$ $=10.0$ ) relative to the "Ratio of GRP per capita (Chuvash Republic / Total for constituent entities of the Russian Federation), \%" $\left(\mathrm{Me}=43.00 \% ; 6^{2}=7.99\right)$. High values of the difference between the ratios of physical volume indices of GRP per capita and GRP per capita (Chuvash Republic $/$ Russian Federation $)\left(\mathrm{Me}=52.75 \% ; 6^{2}=17.48\right)$ allow us to indicate not only the real growth of overall production and services, but also the possibility of increasing GRP per capita through the rise in the price of shipped products. We can clearly see the potential for the development of entrepreneurial activity as a subject of production and as an intermediary in the sales of products. The difference between the indices of industrial production of the Chuvash Republic and the Russian Federation (Me $=2.30 \% ; 6^{2}=38.19$ ) and the ratio of differences between the physical volume indices of GRP per capita and GRP per capita (Chuvash Republic / Russian Federation) and the indices of industrial production (Chuvash Republic and Russian Federation) ( $\left.\mathrm{Me}=8.0 \% ; 6^{2}=12891.33\right)$ signify the risks of gaining entrepreneurial income in the sphere of production. These risks are associated with low profitability and large volumes of industrial production, which limit growth rate of shipped products and reduce working capital turnover. Intermediary services in the sales of shipped products, within the current credit interest, can bring a small, about $2-5 \%$, depending on credit terms, but still income.

So, mediation between the industrial production sector and consumers can become priority for the development of youth entrepreneurship in Chuvashia. Priority is associated with lower competition and requirements for business activities and entrepreneur competencies. It is natural that the service sector remains a significant, according to median values more than $40 \%$, source of income from 
overall business activity [17]. This is due to small volumes, high capital turnover, and as a result, high margin. At the same time, in view of these features, business activity in the service sector develops dynamically in a high competition environment, with changing administrative barriers, increasing requirements for collateral capital and an entrepreneur's competence. Thus, the service sector becomes quite difficult for young people to fulfil themselves as entrepreneurs.

Thus, a significant potential for increasing GRP per capita is hidden in the low price of shipped products in industrial production sectors. This potential can be realized through youth entrepreneurship. Young people as an active part of the labour society can quickly respond to changes in consumers' behaviour, actively motivate them to acquire a certain good, without requiring high remuneration in return.

To identify sectors of the Chuvash economy that create opportunities for young people to fulfil themselves as entrepreneurs, we will assess the competitive advantages of export and import according to the FEACN of the region (table 1).

As a result of the assessment, according to the FEACN the following key competitive advantages have been singled out: 12-Oilseeds and fruits; other seeds, fruits and grains; medicinal plants and plants for technical purposes; straw and fodder; 18-Cocoa and cocoa products; 19-Finished products from cereal grain, flour, starch or milk; flour confectionery goods; 21-Various food products; 32-Tanning or dye-wood extracts; tannins and their derivatives; dyes, pigments and other colouring matters; paints and varnishes; putties and other mastics; printing ink, writing ink, drafting ink; 36Explosives; pyrotechnic products; matches; pyrophoric alloys; some combustible substances; 44-Wood and wood products; charcoal; 90-Optical, photographic, cinematographic, measuring, control, precision, medical or surgical instruments and apparatus; their parts and accessories.

A more detailed analysis of the import hierarchy to the amount of over USD 1 million 2016-2019 (table 2) has allowed us to identify not only the main group of the FEACN (organic chemical compounds; other chemical products; nuclear reactors, boilers, equipment and mechanical devices; parts thereof; vehicles for land transport, except for railway or tramway rolling stock, and their parts and accessories, etc.), but to a greater extent the geography of import.

The global sources of import are China and Germany.

The analysis of the export hierarchy to the amount of over USD 1 million 2016-2019 (table 3) has identified the key areas - Belarus and Kazakhstan, according to the nomenclature - other chemical products; organic chemical compounds; electrical machinery and equipment, parts thereof; sound recording and reproducing equipment, equipment for recording and reproducing television images and sound, their parts and accessories, etc.

Thus, the analysis of the characteristics of the Chuvash economy, including the competitive advantages of export and import according to the FEACN of the region has revealed opportunities for the development of youth entrepreneurship in the industrial production sector according to FEACN 12, 18, 19, 21, 32, 36, 44, 90 with Belarus and Kazakhstan.
Table 1. Competitive advantages of the Foreign Economic Activity Commodity Nomenclature (FEACN) of the Chuvash Republic to the amount of over USD 1 million, 2016-2019.

\begin{tabular}{|c|c|}
\hline $\begin{array}{c}\text { Foreign Economic Activity Commodity } \\
\text { Nomenclature, FEACN }\end{array}$ & Balance \\
\hline FEACN 12 & $4.76 \mathrm{E}+06$ \\
\hline FEACN 18 & $1.46 \mathrm{E}+07$ \\
\hline FEACN 19 & $1.70 \mathrm{E}+07$ \\
\hline FEACN 21 & $5.59 \mathrm{E}+03$ \\
\hline FEACN 25 & $-7.47 \mathrm{E}+06$ \\
\hline FEACN 28 & $2.98 \mathrm{E}+07$ \\
\hline FEACN 29 & $-3.28 \mathrm{E}+08$ \\
\hline FEACN 32 & $1.06 \mathrm{E}+06$ \\
\hline FEACN 34 & $-2.43 E+07$ \\
\hline FEACN 36 & $1.42 \mathrm{E}+06$ \\
\hline FEACN 38 & $-1.64 \mathrm{E}+07$ \\
\hline FEACN 39 & $-3.66 \mathrm{E}+07$ \\
\hline FEACN 44 & $9.74 \mathrm{E}+06$ \\
\hline FEACN 52 & $-3.16 \mathrm{E}+06$ \\
\hline FEACN 54-Group 54 & $-5.93 \mathrm{E}+06$ \\
\hline FEACN 69 & $7.57 \mathrm{E}+06$ \\
\hline FEACN 70 & $-1.55 \mathrm{E}+07$ \\
\hline FEACN 72 & $-1.40 \mathrm{E}+07$ \\
\hline FEACN 74 & $-8.13 \mathrm{E}+06$ \\
\hline FEACN 81 & $-8.31 \mathrm{E}+06$ \\
\hline FEACN 82 & $-3.37 \mathrm{E}+06$ \\
\hline FEACN 84 & $-8.25 E+07$ \\
\hline FEACN 85 & $-1.49 \mathrm{E}+07$ \\
\hline FEACN 86 & $5.92 \mathrm{E}+06$ \\
\hline FEACN 87 & $-5.37 \mathrm{E}+07$ \\
\hline FEACN 89 & $-1.93 \mathrm{E}+06$ \\
\hline FEACN 90 & $5.55 \mathrm{E}+06$ \\
\hline
\end{tabular}

Source: Federal Customs Service. Customs Statistics of Foreign Trade. http://stat.customs.ru/apex/f?p=201:4:3241494250796996 (Accessed 01 November 2019). 
Table 3. Export hierarchy of the Chuvash Republic according to

Table 2. Hierarchy of import to the Chuvash Republic according to the Foreign Economic Activity Commodity Nomenclature (FEACN) to the amount of over USD 1 million, 2016-2019.

\begin{tabular}{|c|c|c|}
\hline FEACN & Country & Amount \\
\hline 29-Organic chemical compounds & \begin{tabular}{|l|} 
China, United Kingdom, \\
Belgium, Germany, India, \\
Belarus, Switzerland, USA, \\
Italy, Puerto Rico, Poland
\end{tabular} & $3.91 \mathrm{E}+08$ \\
\hline 38-Other chemical products & $\begin{array}{l}\text { Belarus, France, China, } \\
\text { Norway, Belgium, Republic } \\
\text { of Korea }\end{array}$ & $1.84 \mathrm{E}+08$ \\
\hline $\begin{array}{l}\text { 84-Nuclear reactors, boilers, } \\
\text { equipment and mechanical } \\
\text { devices; parts thereof }\end{array}$ & $\begin{array}{l}\text { Germany, Switzerland, } \\
\text { Italy, Republic of Korea, } \\
\text { Italy, China, Ukraine, } \\
\text { Sweden, Poland, } \\
\text { Netherlands, Belarus, } \\
\text { Serbia, Austria, Croatia }\end{array}$ & $1.20 \mathrm{E}+08$ \\
\hline $\begin{array}{l}\text { 87-Vehicles for land transport, } \\
\text { except for railway or tramway } \\
\text { rolling stock, and their parts and } \\
\text { accessories }\end{array}$ & \begin{tabular}{|l|} 
Belarus, Italy, China, \\
Republic of Korea, Austria
\end{tabular} & $6.84 \mathrm{E}+07$ \\
\hline $\begin{array}{l}\text { 85-Electrical machinery and } \\
\text { equipment, parts thereof; } \\
\text { sound recording and } \\
\text { reproducing equipment, } \\
\text { equipment for recording and } \\
\text { reproducing television images } \\
\text { and sound, their parts and } \\
\text { accessories }\end{array}$ & $\begin{array}{l}\text { Germany, China, Poland, } \\
\text { Republic of Korea, Belarus, } \\
\text { Sweden }\end{array}$ & $5.44 \mathrm{E}+07$ \\
\hline 39-Plastics and plastic products & $\begin{array}{l}\text { China, Japan, France, } \\
\text { Germany, USA }\end{array}$ & $3.83 \mathrm{E}+07$ \\
\hline $\begin{array}{l}\text { 34-Soap, surfactants, } \\
\text { detergents, lubricants, artificial } \\
\text { and ready-made waxes, } \\
\text { cleaning or polishing } \\
\text { compounds, candles and } \\
\text { similar products, modeling } \\
\text { pastes, plasticine, dental wax } \\
\text { and dental compositions based } \\
\text { on gypsum }\end{array}$ & $\begin{array}{l}\text { Italy, Sweden, Germany, } \\
\text { Belgium }\end{array}$ & $2.43 \mathrm{E}+07$ \\
\hline 70-Glass and articles thereof & Germany, China & $1.55 \mathrm{E}+07$ \\
\hline 72-Ferrous metals & China, United Kingdom & $1.40 \mathrm{E}+07$ \\
\hline $\begin{array}{l}\text { 90-Optical, photographic, } \\
\text { cinematographic, measuring, } \\
\text { control, precision, medical or } \\
\text { surgical instruments and } \\
\text { apparatus; their parts and } \\
\text { accessories } \\
\end{array}$ & Austria, Germany & $8.53 \mathrm{E}+06$ \\
\hline $\begin{array}{l}\text { 81-Other base metals; metal- } \\
\text { ceramics; articles thereof }\end{array}$ & Republic of Korea, USA & $8.31 \mathrm{E}+06$ \\
\hline 74-Copper and copper products & Austria & $8.13 \mathrm{E}+06$ \\
\hline $\begin{array}{l}\text { 25-Salt; sulfur; earth and stone; } \\
\text { plastering materials, lime and } \\
\text { cement }\end{array}$ & Ukraine & $7.47 \mathrm{E}+06$ \\
\hline $\begin{array}{l}\text { 54-Group } 54 \text { chemical yarns; } \\
\text { flat and similar yarns from } \\
\text { chemical textile materials }\end{array}$ & China & $5.93 \mathrm{E}+06$ \\
\hline $\begin{array}{l}\text { 82-Tools, accessories, cutlery, } \\
\text { spoons and forks made of base } \\
\text { metals; their parts made of } \\
\text { base metals }\end{array}$ & Germany & $3.37 \mathrm{E}+06$ \\
\hline $\begin{array}{l}\text { 28-Products of inorganic } \\
\text { chemistry; inorganic or organic } \\
\text { compounds of precious metals, } \\
\text { rare earth metals, radioactive } \\
\text { elements or isotopes }\end{array}$ & China & $3.19 \mathrm{E}+06$ \\
\hline 52-Cotton & Republic Of Moldova & $3.16 \mathrm{E}+06$ \\
\hline $\begin{array}{l}\text { 89-Ships, boats and floating } \\
\text { structures }\end{array}$ & United Kingdom & $1.93 \mathrm{E}+06$ \\
\hline 21-Various food products & USA & $1.07 \mathrm{E}+06$ \\
\hline
\end{tabular}

01 November 2019). the Foreign Economic Activity Commodity Nomenclature (FEACN) to the amount of over USD 1 million, 2016-2019.

\begin{tabular}{|c|c|c|}
\hline FEACN & Country & Amount \\
\hline 38-Other chemical products & $\begin{array}{l}\text { Belarus, } \\
\text { Kazakhstan, } \\
\text { Republic of } \\
\text { Moldova, India, } \\
\text { Brazil, Poland, } \\
\text { Lithuania, } \\
\text { Mongolia, } \\
\text { Colombia, } \\
\text { Azerbaijan, } \\
\text { France, Czech } \\
\text { Republic, }\end{array}$ & $1.67 \mathrm{E}+08$ \\
\hline 29-Organic chemical compounds & $\begin{array}{l}\text { Kazakhstan, } \\
\text { Belarus, USA, } \\
\text { Italy, British } \\
\text { Virgin Islands, } \\
\text { Egypt, China, } \\
\text { Turkey, Slovakia, } \\
\text { Nigeria }\end{array}$ & $6.33 \mathrm{E}+07$ \\
\hline $\begin{array}{l}\text { 85-Electrical machinery and } \\
\text { equipment, parts thereof; sound } \\
\text { recording and reproducing } \\
\text { equipment, equipment for recording } \\
\text { and reproducing television images } \\
\text { and sound, their parts and accessories }\end{array}$ & $\begin{array}{l}\text { Belarus, } \\
\text { Kazakhstan, } \\
\text { Azerbaijan, } \\
\text { Bangladesh, } \\
\text { Uzbekistan, } \\
\text { Lithuania }\end{array}$ & $3.95 \mathrm{E}+07$ \\
\hline $\begin{array}{l}\text { 84-Nuclear reactors, boilers, equipment } \\
\text { and mechanical devices; parts thereof }\end{array}$ & $\begin{array}{l}\text { Belarus, } \\
\text { Kazakhstan, } \\
\text { Ukraine, } \\
\text { Kyrgyzstan, } \\
\text { Uzbekistan }\end{array}$ & $3.72 \mathrm{E}+07$ \\
\hline $\begin{array}{l}\text { 28-Products of inorganic chemistry; } \\
\text { inorganic or organic compounds of } \\
\text { precious metals, rare earth metals, } \\
\text { radioactive elements or isotopes }\end{array}$ & $\begin{array}{l}\text { Belarus, Serbia, } \\
\text { Czech Republic, } \\
\text { Ukraine, Italy, } \\
\text { Uzbekistan, } \\
\text { Kazakhstan }\end{array}$ & $3.30 \mathrm{E}+07$ \\
\hline $\begin{array}{l}\text { 19-Finished products from cereal grain, } \\
\text { flour, starch or milk; flour confectionery } \\
\text { goods }\end{array}$ & Ukraine, China & $1.70 \mathrm{E}+07$ \\
\hline $\begin{array}{l}\text { 87-Vehicles for land transport, except } \\
\text { for railway or tramway rolling stock, } \\
\text { and their parts and accessories }\end{array}$ & $\begin{array}{l}\text { Kazakhstan, } \\
\text { Azerbaijan, } \\
\text { Ukraine, Belarus }\end{array}$ & $1.47 \mathrm{E}+07$ \\
\hline 18-Cocoa and cocoa products & China & $1.46 \mathrm{E}+07$ \\
\hline $\begin{array}{l}\text { 90-Optical, photographic, } \\
\text { cinematographic, measuring, control, } \\
\text { precision, medical or surgical } \\
\text { instruments and apparatus; their parts } \\
\text { and accessories }\end{array}$ & Kazakhstan, India & $1.41 \mathrm{E}+07$ \\
\hline 44-Wood and wood products; charcoal & $\begin{array}{l}\text { Kazakhstan, } \\
\text { Azerbaijan }\end{array}$ & $9.74 \mathrm{E}+06$ \\
\hline 69-Ceramic products & Kazakhstan & $7.57 \mathrm{E}+06$ \\
\hline $\begin{array}{l}\text { 86-Railway locomotives or tram } \\
\text { motor cars, rolling stock and parts } \\
\text { thereof; track equipment and devices } \\
\text { for railways or tramways and parts } \\
\text { thereof; mechanical (including } \\
\text { electromechanical) signalling } \\
\text { equipment of all types }\end{array}$ & Kazakhstan & $5.92 \mathrm{E}+06$ \\
\hline $\begin{array}{l}\text { 12-Oilseeds and fruits; other seeds, } \\
\text { fruits and grains; medicinal plants } \\
\text { and plants for technical purposes; } \\
\text { straw and fodder }\end{array}$ & Poland, Germany & $4.76 \mathrm{E}+06$ \\
\hline 39-Plastics and plastic products & USA & $1.69 \mathrm{E}+06$ \\
\hline $\begin{array}{l}\text { 36-Explosives; pyrotechnic products; } \\
\text { matches; pyrophoric alloys; some } \\
\text { combustible substances }\end{array}$ & Uzbekistan & $1.42 \mathrm{E}+06$ \\
\hline 21-Various food products & United Kingdom & $1.08 \mathrm{E}+06$ \\
\hline $\begin{array}{l}\text { 32-Tanning or dye-wood extracts; } \\
\text { tannins and their derivatives; dyes, } \\
\text { pigments and other colouring matters; } \\
\text { paints and varnishes; putties and other } \\
\text { mastics; printing ink, writing ink, } \\
\text { drafting ink }\end{array}$ & Belarus & $1.06 \mathrm{E}+06$ \\
\hline
\end{tabular}

Source: Federal Customs Service. Customs Statistics of Foreign Trade. http://stat.customs.ru/apex/f?p=201:4:3241494250796996 (Accessed 01 November 2019). 
region's economy, and as a result, the conditions for the

\section{DISCUSSION OF RESULTS}

Establishment of a youth regional export centre will encourage realization of opportunities of the Chuvash economy for the development of entrepreneurship among young people, primarily in the industrial production sector according to FEACN 12, 18, 19, 21, 32, 36, 44, 90 with Belarus and Kazakhstan, and also within the import substitution policy will reduce import dependence on China and Germany according to FEACN 21, 25, 28, 29, 34, 38, 39, 52, 54 (group 54), $70,72,74,81,82,84,85,87$. This centre will take the shape of a youth initiative implemented within the limits of the Strategy and the Federal law on the development of small and medium businesses, especially with respect to Article 25.3. "The Russian Export Centre" [18, 19].

The financial content of the youth regional export centre should include human capital investment, creation of intellectual resources that promote not only innovative products and technologies [20], but also generate projects to reduce transaction costs in foreign economic activity. At the same time, a young intellectual class of society will be actively formed that can change the existing raw materials-based structural specialization of the Russian economy.

Thus, young people under the leadership of leading Russian and foreign representatives of importing and exporting companies will participate in the development of proposals expressing interests of small and medium businesses, methodological recommendations and other materials on export activities $[21,22]$. A new class of young entrepreneurs, integrated into the world trade turnover, will contribute to the active development of the economy of Chuvashia.

\section{CONCLUSION}

The conducted research carries a certain form of new knowledge, its increment, which is related to changes in understanding of the role of young people as labour resources employed in the system of production, distribution, exchange and consumption of goods. At the same time, differences in the economic opportunities of a certain constituent entity of the Russian Federation are a source of self-motion of the Russian economy.

The study of the development of regional youth entrepreneurship as a phenomenon is associated with revealing contradictions in the economic system of the region, its structure. As a reduced functional basis that can single out a set of tools for resolving contradictions, foreign economic activity is set as a priority in the Federal law on strategic planning.

Foreign economic activity in the context of changes in the world order, a decline in world trade and increased global competition promotes its influence on the development of youth entrepreneurship.

Modern youth exists in the reality of the world economic system, occupying a special position in the structure of unemployment, entrepreneurship, poverty among working people, etc. All countries are active in solving problems caused by structural changes in the world economic system, but in different ways. In LMICs prevail measures for stimulation selfemployment and entrepreneurship in construction, agriculture, and street trade. Most self-employed jobs in LMICs are associated with low productivity and income, and as a result, many of the self-employed and their families remain poor. In HICs predominate ESJSA measures in the context of ALMP - subsidized employment through PEPs, assistance in job creation in private business through wage subsidies for young people, training young people in professional skills at work or outside work.

Review of Russian regulatory literature allows us to distinguish the Constitutional right to conduct business, to define the image of an entrepreneur as an independent (doing business at his own risk) business entity whose goal is to profit from using property, selling goods, performing work or rendering services.

State regulation of business activity starts from the moment of its mandatory registration. Mandatory registration is clearly expressed in contradictions of Article 23 of the Civil Code of the Russian Federation "The Citizen's Business Activity" in item 5 which states that citizens are entitled to exercise productive or other kinds of economic activity in the area of agriculture without forming a legal entity on the basis of an agreement on establishing a peasant's farm made in compliance with the law on a peasant's farm [23]. At the same time, as the head of a peasant's farm may act a citizen registered as an individual businessman.

The Federal law on the development of small and medium businesses, which sets out the main goals and principles of state policy in the development of small and medium businesses, as well as a variety of support measures, is an essential regulatory legal act defining the possibilities of conducting business.

In Chuvashia, the unity of the Constitutional law, the norms of the Civil Code of the Russian Federation [23], and the Federal law on the development of small and medium businesses is realized in the Strategy of socioeconomic development of the Chuvash Republic. The main message of the Strategy is to ensure implementation of a set of measures for promotion of business initiatives and involvement of entrepreneurs in export activities.

The analysis of the opportunities of the Chuvash economy for the development of youth entrepreneurship has revealed industrial export sectors according to FEACN 12, 18, 19, 21, 32, 36, 44, 90 with Belarus and Kazakhstan. Mediation between the industrial production sector and consumers can become a priority for the development of youth entrepreneurship in Chuvashia. This is especially 
[11] N. O'Higgins. "This Time It's Different? Youth Labor Markets during 'The Great Recession'”, in Comparative Economic Studies, 2012, vol. 54, no. 2, pp. 395-412.

[12] Choudhry, M.; Marelli, E.; Signorelli, M. 2012. "Youth Unemployment and the Impact of Financial Crises", in International Journal of Manpower, Vol. 33, No. 1, pp. 76-95.

[13] N. O'Higgins. "Rising to the Youth Employment Challenge: New Evidence on Key Policy Issues". International Labour Office - Geneva: ILO, 2017. 235 p.

[14] T. H. Gindling, D. Newhouse. "Self-employment in the Developing World", in World Development, 2014, vol. 56, pp. 313-331.

[15] N. V. Ketko, O. E. Akimova. "Research of Motivational Preferences of Entrepreneurs for the Development of Russian Small Business". Economic Analysis: Theory and Practice. 2016. No. 9 (456). Pp. 27-38.

[16] Programme on Youth Employment. The ILO's. Youth Employment Programme (YEP) Unit. Employment Policy Department. International Labour Office. Switzerland. Global Employment Trends for Youth 2015. https://www.ilo.org/global/topics/youthemployment/lang--en/index.htm

[17] Small and Medium Businesses in Chuvashia. http://mb.cap.ru/default.aspx (Accessed 01 November 2019).

[18] G. V. Simonyan. "Models of State Support for Export on the International Market". National Interests: Priorities and Security. 2019. Vol. 15. No. 1 (370). Pp. 111-123. DOI: 10.24891/ni.15.1.111

[19] A. A. Nikonova. "Models of Technological Growth of the Russian Economy: Problems and Solutions". National Interests: Priorities and Security. 2018. Vol. 14. No. 3 (360). Pp. 427-451. DOI: 10.24891/ni.14.3.427

[20] V. Smirnov, V. Semenov, E. Kadyshev, A. Zakharova, E. Perfilova. "Management of Development Efficiency of the Russian Economy". The European Proceedings of Social \& Behavioral Sciences (SCT 2018). Published by the Future Academy. 2019. ISSN: 2357-1330, no. 218, pp. 1871-1877. doi:https://dx.doi.org/10.15405/epsbs.2019.03.02.218.

[21] V. V. Smirnov, T. V. Talanova, A. N. Zakharova, G. S. Dulina, I. B. Getskina, N. V. Huraskina. "Predictive Analysis of the Russian Entrepreneurship Development". Proceedings of the 32nd International Business Information Management Association Conference (IBIMA), 2018, pp. 6949-6958.

[22] V. V. Smirnov, V. L. Semenov, E. N. Kadyshev, A. N. Zakharova, I. A. Guschin, T. V. Kravchenko, M. N. Yaklashkin, O. A. Filippova. "Effective Public 
[23] Civil Code of the Russian Federation. 30.11.1994 N 51-FZ (amended 18.07.2019 (revised and supplemented, entered into force 01.10.2019) // Legislation Bulletin of the Russian Federation, 05.12.1994, N 32, article 3301; Rossiyskaya Gazeta, N 238-239, 08.12.1994. 